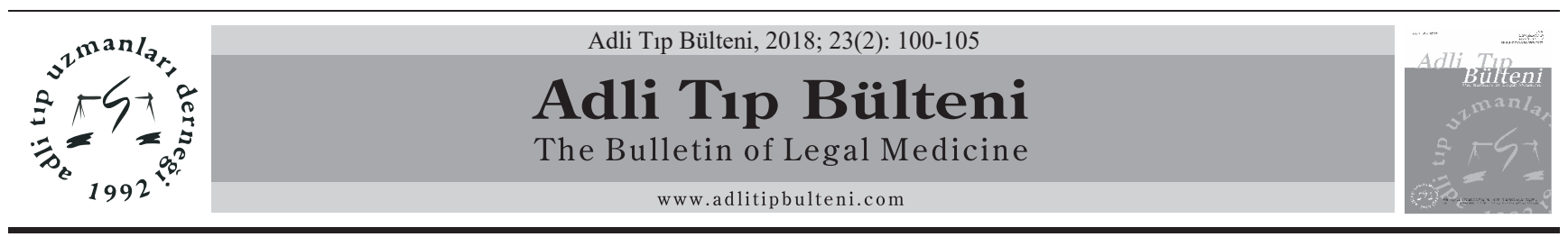

ARAŞTIRMA / RESEARCH ARTICLE

doi: $10.17986 / \mathrm{blm} .2017331583$

\title{
18-65 Yaş Aralığındaki Kişilerde Hukuki Ehliyetin Değerlendirilmesi
}

\author{
An Evaluation of Legal Capacity in 18-65 Years Old Population
}

Halil İlhan Aydoğdu, Mehmet Askay, Güven Seçkin Kırcı, Erdal Özer

Karadeniz Teknik Üniversitesi Tıp Fakültesi Adli Tıp Anabilim Dal, Trabzon

\begin{abstract}
Özet
Amaç: Medeni hukuk, çağdaş toplumlarda kişilere belirli hak ve ehliyetler tanımlamıştır. Fiil ehliyeti kişilerin haklarını kullanmasını, sorumluluklar edinebilmesini gerektiren hak ve ödevleri kapsamaktadır. Kişilerin çeşitli sebeplerle fiil ehliyetine sahip olmaması durumlarında hukuk sistemi uzman tıbbi bilirkişilerden görüş almaktadır. Çalışmamızda 18-65 yaş aralığındaki kişilerin hukuki ehliyetin değerlendirilmesi ve literatüre katkıda bulunmak amaçlanmıştır.

Gereç ve Yöntem: 01/01/2015 -31/12/2016 tarihleri arasında Adli Tıp Anabilim Dalı'na hukuki ehliyetin değerlendirilmesi için gönderilen hastalardan 18-65 yaş arasında kalanlara düzenlenen adli raporlar geriye dönük olarak incelendi.

Bulgular: İncelenen 108 olgunun yaşları 18-64 arasında değişmekteydi. Alınan anamnez, incelenen tıbbi evrak, yapılan tetkikler, testler ve ruhsal durum muayenesi neticesinde şahıslardan 56'sının $(\% 51,9)$ TMK 405. madde kapsamında kısıtlanmasının, 3'ünün $(\% 2,8)$ TMK 408. madde kapsamında isteği doğrultusunda kısıtlanabileceği, 11 'inin $(\% 10,2)$ TMK 406. madde kapsamında savurganlığı, kötü yaşam tarzı ve malvarlığını kötü yönetmesi sebebiyle kendisini ya da ailesini darlık veya yoksunluğa düşürme tehlikesinin belirlenmesi durumunda vesayet altına alınabileceği, 4'üne $(\% 3,7)$ yasal danışman atanmasının uygun olacağı belirtilmiş olup, $34(\% 31,5)$ kişi hakkında da vesayet altına alınmasını gerektirir bir halinin olmadığı kararı verildi.

Sonuç: Bu çalışmada, hukuki ehliyet açısından değerlendirilen 18-65 yaş aralığındaki kişilerde en sık mental retardasyon saptanmış olup bu durumun geriatrik popülasyondan farklılık gösterdiği tespit edilmiştir. Ayrıca elde edilen bulgular geriatrik olmayan yaş gruplarında hukuki ehliyetin değerlendirilmesinde özel bir yaklaşım sergilenmesi gerektiğini göstermektedir.
\end{abstract}

Anahtar Kelimeler: Vesayet; Hukuki Ehliyet; Adli Psikiyatri.

\section{Giriş}

Medeni hukuk çağdaş toplumlarda kişilere belirli hak ve ehliyetler tanımlamıştır. Her insanın hak ehliyeti mevcuttur. 4721 sayılı Türk Medeni Kanunu (TMK) 8 ve 9.

Sorumlu Yazar: Dr. Mehmet Askay

Karadeniz Teknik Üniversitesi Tip Fakültesi Adli Tip Anabilim Dal, Trabzon

E-mail:mehmetaskay@hotmail.com

Geliş: 09.06.2017 Düzeltme: 07.07.2017 Kabul: 26.09.2017

\section{Abstract}

Objective: In modern societies, civil law defines specific rights and capacities for individuals. The legal capacity of a person to use those rights encompasses the rights and functions required to be able to acquire responsibilities. When individuals do not have legal capacity for various reasons, the legal system takes the view of those with specialist medical knowledge. To the best of our knowledge, there are no studies in literature which have evaluated the legal capacity of age groups other than geriatrics.

Materials and Methods: A retrospective examination was made of the forensic reports of 18-65 years old patients who were referred to the Forensic Medicine Department for evaluation of legal capacity in the period 01/01/2015-31/12/2016.

Results: A total of 108 cases were evaluated in the age range of 18-64 years. According to the anamnesis taken, the medical records examined, the tests applied and the psychological status examination, the decisions given were that $56(51.9 \%)$ were restricted in the context of item 405 TMK (Turkish Civil Code), 3 (2.8\%) could be restricted on request in the context of item 408 TMK, 11 $(10.2 \%)$ could be taken into custody in situations determined as threatening him/herself or his/her family with hardship or poverty through extravagance, poor lifestyle and poor management of assets, $4(3.7 \%)$ were defined as eligible for the appointment of a legal advisor and $34(31.5 \%)$ were not determined with any state requiring custody.

Conclusion: In this study, it was found that the most common disorder in people between the ages of 18-65 that affects legal capacity was mental retardation. The obtained findings indicated that a special approach should be taken in the evaluation of the legal capacity of the non-geriatric age group.

Keywords: Custody; Legal Capacity; Forensic Psychiatry.

Maddesinde, kişilerin haklara ve borçlara ehil olmada eşit oldukları, fiil ehliyeti tam olan kişilerin hak edinebilmesinin ve borç altına girebilmesinin kendi fiilleriyle mümkün olduğundan bahsedilir. Hak ehliyeti kavramı canlı ve tam doğumla (rahim içindeki süre de dahil olmak üzere) ölüm arası süreyi kapsar. Örneğin, çocuklar hak ehliyetini hukuken sağ olarak tamamıyla doğmak şartıyla ana rahmine düştüğü andan başlayarak elde eder.

Fiil ehliyeti ise kişilerin haklarını kullanmasını, sorumluluklar edinebilmesini gerektiren hak ve ödevleri 
kapsamaktadır. Fiil ehliyeti şahısların kamu düzeni ve diğer bireylerle ilişkilerindeki sınır, hak, yetki ve ödevleri tanımlamaktadır (1).

TMK fiil ehliyetine sahip olabilmek için gerekli şartları şu şekilde sıralamıştır; Ergin olmak, ayırt etme gücüne sahip olmak ve kısıtlı olmamak.

Ergin olmak TMK Madde 11'de genel kural olarak 18 yaşını doldurmak olarak tanımlanmaktadır. Bunun yanında evlilikle ya da 15 yaşını dolduranlarda mahkeme kararıla bir birey ergin k1lınabilmektedir. Kısıtlı olmama şartı; akıl hastalığı, kötü yönetim tarzı, alkolmadde bağımlığı ya da kendi talebi ile kısıtlanmamış olmayı veya bir sene veya daha fazla hapis cezası yememiş olmayı gerektirmektedir. Ayırt etme gücü kavramı ile anlatılmak istenen kişilerin akla uygun şekilde hareket edebilme, eylemlerinin neden ve sonuçlarını kavrayabilme (idrak edebilme) yetisidir. TMK Madde 13 ’te, yaşının küçüklüğü yüzünden veya akıl hastalığı, akıl zayıflı̆̆ı, sarhoşluk ya da bunlara benzer sebeplerden biriyle akla uygun biçimde davranma yeteneğinden yoksun olmayan herkesin ayırt etme gücüne sahip olduğundan bahsedilmektedir. Bireyin algılama yeterliliği, istekleri ve bunları yönetebilme ögelerini içeren ayırt etme kabiliyeti çeşitli durumlarda bozulabilmektedir (2). Bu durumlardan bazıları kişinin kısıtlanmasını da gerektirmektedir. TMK $404-408$ maddeleri arasında vesayet gerektiren hallere yer verilmiştir. Bunlar sırasıyla küçüklük, akıl hastalığı veya zayıflığı, savurganlık, alkol veya uyuşturucu madde bağımlılığı, kötü yaşama tarzı, kötü yönetim, özgürlügüü bağlayıcı ceza ve şahsın kendi isteğidir.

Yukarıda bahsedilen vesayet gerektiren hallerin tespiti halinde vasilik makamı oluşturulabilir. Vasi, vesayet altındaki küçüğün veya kısıtlının kişiliği ve malvarlığı ile ilgili bütün menfaatlerini korumak ve hukuki işlemlerde onu temsil etmekle yükümlüyken, yasal danışman daha sınırlı (dava açma, taşınmazların alımı, satımı, bağışlama vb.) yetkilere sahiptir. Bunun yanında kişilerin vesayet altına alınması için yeterli bir sebep bulunmamakla beraber, bir kişinin malvarlığını kendi başına yönetmek veya bunun için temsilci atamak gücünden yoksun olması halinde TMK 426, 427, 428 ve 429'uncu maddeleri gereğince kayyım ya da yasal danışman da tayin edilebilmektedir (1).

Özetlemek gerekirse; vasi, kısıtlanan bireyin malvarlığı açısından menfaatlerini korumak ve hukuki işlemlerinde onu temsil etmekle yükümlü kanuni temsilci iken, yasal danışman; fiil ehliyeti tamamen kısıtlanmayan bireylere atanan bazı işlemleri yapma yetkilerini malvarlığı sahibinin görüşünü alarak gerçekleștirebilen yasal temsilcidir.
Kayyım ise kişilerin fiil ehliyetini sınırlandıran vesayetin aksine daha çok danışmanlık gibi hizmet verir. Temsil, yönetim ve iradi kayyımlık diye üç türü mevcuttur. Temsil kayyımı vasi gibi hareket edebilirken; yönetim kayyımı, daha çok malvarlığı ile ilgili değerlerin temsilinde görevlidir. Hastalık, yaşlılık veya tecrübesizlik sebebiyle atanan kayyımlar da iradi kayyım olarak görev yaparlar.

Vesayet altına alınma talebi ile şahısların kendi başvuruları, yakınlarının başvuruları ya da kendiliğinden harekete geçme ilkesi gereği mahkemece tespit edilen durumlarda dava açılabilmektedir. Bu nedenle, akıl hastalığı veya zayıflı̆̆ı, savurganlık, alkol veya uyuşturucu madde bağımlılı̆̆ı durumlarının tespiti yanında kişinin yaşlılığı, deneyimsizliği veya ağır hastalığı gibi durumların tespitinde de adli psikiyatrik değerlendirme önem arz etmektedir (3). Bu değerlendirme hekim-hasta ilişkisinin dışında hukuk profesyonelleri ve hekimler arasında işbirliği gerektirmektedir.

Vesayet altına alma/alınma taleplerine sıklıkla geriatrik yaş grubunda rastlanmaktadır. Çünkü yaşlı popülasyonda birçok fiziki ve mental rahatsızlıklara rastlanmakta ve bu durumlar kişilerin hukuki ehliyetlerini kullanmasını engellemektedir (4). Bunun yanı sira geriatrik olmayan popülasyonda da hukuki ehliyetin değerlendirilmesine ihtiyaç duyulmaktadır.

$\mathrm{Bu}$ çalışmada, kişilerin vesayet altına alınmasını gerektirecek hallerinin beklenmediği yaş grupları üzerinden hukuki ehliyet değerlendirmesi, bu süreçte izlenecek yol ve raporlandırmada kullanılacak ortak terminolojiyle ilgili bilgi düzeyini artırmak ve de bu yaş gruplarındaki kısıtlanma sebeplerine dikkat çekmek amaçlanmıştır.

\section{Gereç ve Yöntem}

01/01/2015 -31/12/2016 tarihleri arasında Adli Tip Anabilim Dalı'na hukuki ehliyetin değerlendirilmesi için gönderilen 174 kişiden çocuklar ve yaşlı popülasyon d1şında kalan 18-65 yaş arasındaki 108 kişi hakkında düzenlenen adli raporlar geriye dönük olarak incelendi. 108 kişinin yaş, cinsiyet, muayenesi sonucu tespit edilen hastalık veya hastalıkları ile düzenlenen raporlarının sonuçları değerlendirildi. İstatistiki analizler için IBM SPSS versiyon 23 programı kullanıld 1 ve $p<0,05$ anlamlı kabul edildi.

\section{Bulgular}

Çalışmaya dahil edilen 108 kişinin yaşları 18 ile 65 arasında değişmekte olup yaşlarının ortalaması $37,9 \pm 14,24$, median yaş 37 olarak tespit edildi. Kişilerden 25 'inin $(\% 23,1)$ 18-24 (genç erişkin) yaş grubunda, 62'sinin $(\% 57,4)$ 25-54, 21 'inin $(\% 9,4)$ 55-64 yaş grubunda 
olduğu tespit edildi. Hukuki ehliyet değerlendirmesi yapılan şahısların 66'sı (\%61) erkek, 42'si (\%39) kadındı.

Şahısların yapılan muayeneleri ve tetkikleri sonucunda tespit edilen tıbbi durumlar Grafik 1'de gösterilmiştir. Psikiyatrik tanılar DSM-5 tanı kriterleri kullanılarak konulmuş olup yine bu kriterlere göre sınıflandırılmıştır. Psikiyatrik rahatsızlık tespit edilmeyip; serebral palsi sekeli $(n=2)$, serebrovasküler hastalıkların sekelleri $(n=2)$, ileri derecede kronik obstrüktif akciğer hastalığı $(n=1)$, epilepsi $(n=1)$, gelişim bozukluğu $(n=1)$ ve bilateral ileri gonartroz $(n=2)$ tespit edilen 9 kişi "fiziki hastalıklar" grubuna, otizm $(n=1)$, sosyal işlev yetersizliği $(n=1), B$ kümesi kişilik ( $n=1)$, antisosyal kişilik $(n=1)$, karaciğer hastalığına sekonder demans $(n=1)$, parkinson-demans $(n=1)$ ya da depresyon $(n=1)$ hastalı̆̆ de "diğer hastalıklar" grubuna dahil edildi.
Alınan anamnez, incelenen tibbi evrak, yapilan tetkikler, testler ve ruhsal durum muayenesi neticesinde, şahıslardan 56'sının $(\% 51,9)$ TMK 405. madde kapsamında kisitlanmasının, 3’ünün $(\% 2,8)$ TMK 408. madde kapsamında isteği doğrultusunda kısitlanabileceği, 11’inin $(\% 10,2)$ TMK 406. madde kapsamında savurganlığı, kötü yaşam tarzı ve malvarlığını kötü yönetmesi sebebiyle kendisini ya da ailesini darlık veya yoksunluğa düşürme tehlikesinin belirlenmesi durumunda vesayet altına alınabileceği, 4'üne $(\% 3,7)$ yasal danışman atanmasının uygun olacağı belirtilmiş olup, $34(\% 31,5)$ kişi hakkında da vesayet altına alınmasını gerektirir bir halinin olmadığı kararı verildi. Verilen vesayet kararları Grafik 2'de gösterildi. Bu kararlar gruplandığında; 74 (\%68,5) kişinin kısıtlanmasının gerekli olduğu, $34(\% 31,5)$ kişinin ise kısıtlanmasına gerek olmadığı sonucuna varıldığı tespit edildi.

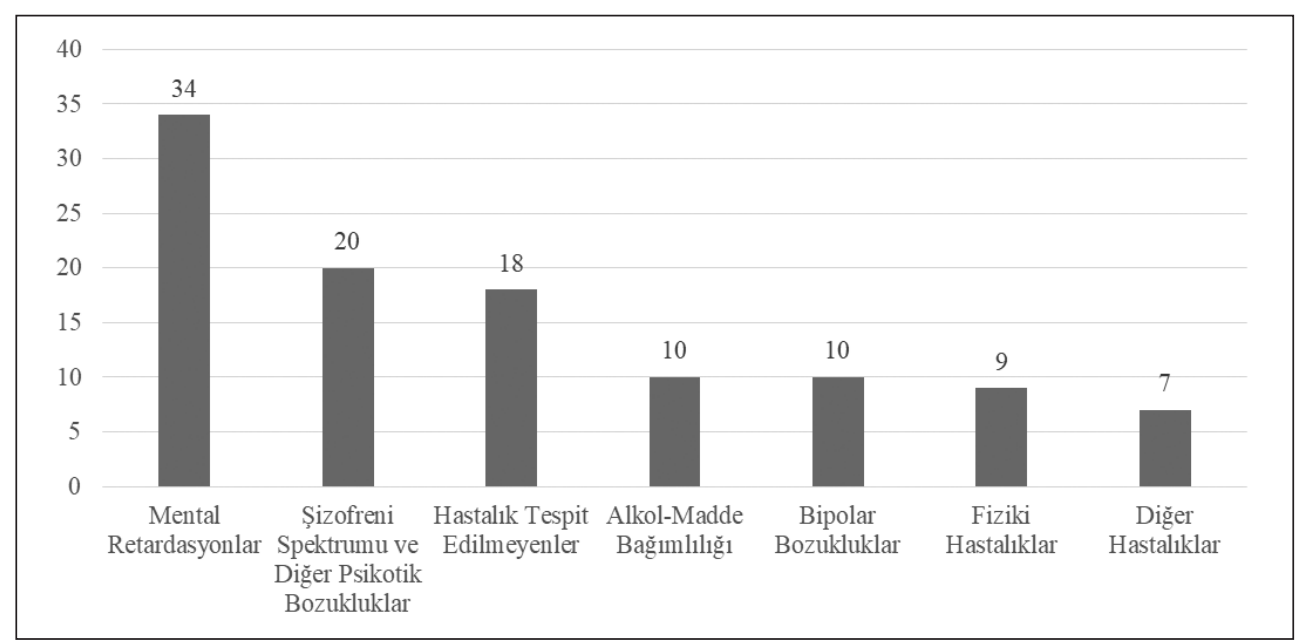

Grafik 1. Tanılar.

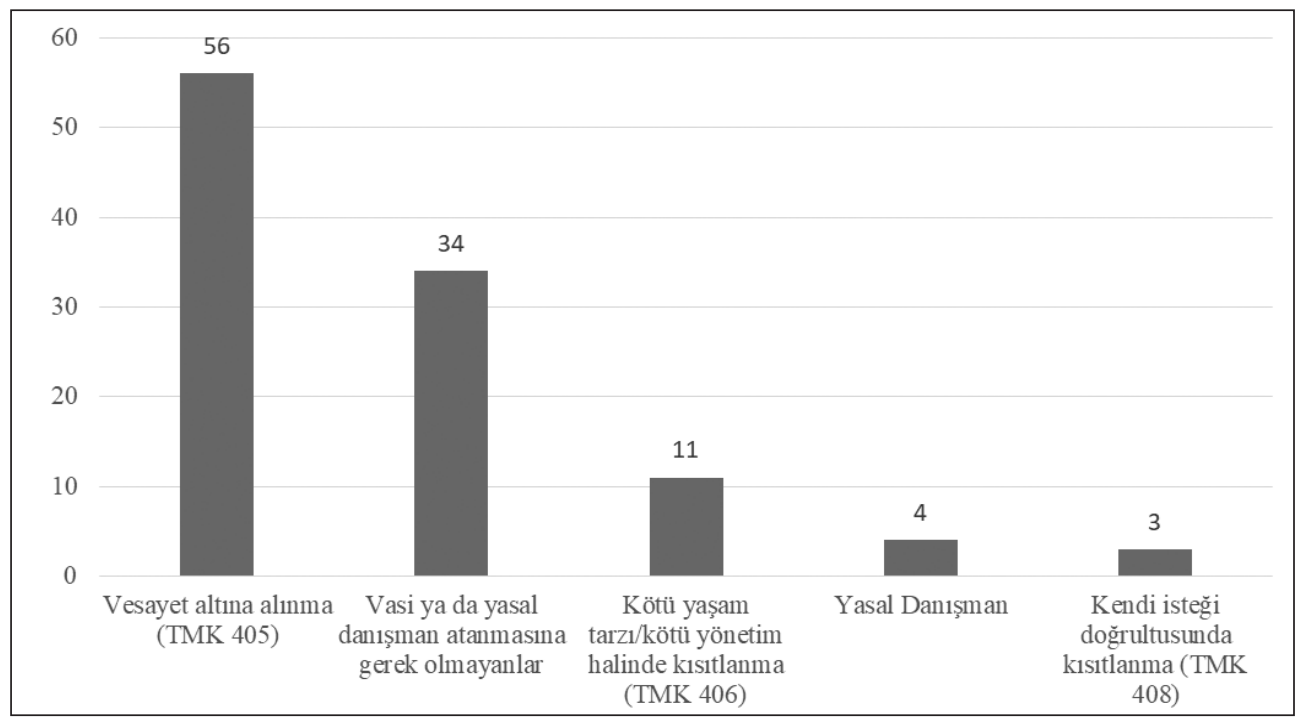

Grafik 2. Rapor Sonuçları. 
TMK 408. madde kapsamında isteği doğrultusunda kısıtlanabileceği kararı verilen üç olgunun ikisinde fiziki/ ortopedik hastalıklar (mobilize olmasını engelleyecek nitelikte) olduğu, birinin ise Parkinson hastası olduğu tespit edildi.

Kişilerin yaş grubu ile tıbbi durumları arasındaki ilișki incelendiğinde; 18-24 yaș grubundaki hastaların \%64'ünün (n=16) "Mental Retardasyon" tanıs1 aldığ1, $\% 12$ 'sinde $(n=3)$ fiziki hastalıklar tespit edildiği, 25-54 yaş grubunda ise en çok tespit edilen klinik tabloların 14'er hasta $(\% 22,6)$ ile "Şizofreni Spektrumu ve Diğer Psikotik Bozukluklar" ve "Mental Retardasyon" olduğu, 55-64 yaş aralığında ise; bu oranların "Mental Retardasyon" için \%19 (n=4), "Şizofreni Spektrumu ve Diğer Psikotik Bozukluklar" için \%28,6 (n=6) olduğu tespit edildi. Yaş grupları ile kişilerin kısıtlanmasının gerekip gerekmediğine dair verilen sonuç arasındaki ilişki incelendiğinde; 18-24 yaş grubundakilerin \%80'inin ( $\mathrm{n}=20)$, $25-54$ yaş grubundakilerin \% $\%$,7'sinin $(n=37), 55-64$ yaş grubundakilerin \%81'inin (n=17) k1sıtlanması gerektiği kararına varılmış olup bu ilişski anlamlı değildi $(p>0,05)$.

Herhangi bir hastalık tespit edilmeyen şahıslar çıkarılarak, kişilerin aldıkları tanılar ile rapor sonuçlarının yüzdesel dağılımı Tablo 1'de gösterilmiştir.

\section{Tartışma ve Sonuc}

Gerçek kişilerin ehliyetleri hukukun önemli alanlarından birisidir. Bunlar içerisinde fiil ehliyeti ve bu ehliyeti kullanma yetisinin tespiti hukuk devletlerinde büyük önem taşımaktadır. Öyle ki hukuk sistemi kişilerin fiil ehliyetinin olmadığına ya da fiil ehliyetini kullanmasına engel olabilecek durumların tespitini yaptırarak kişilerin korunması amacıyla kısıtlanmalarını sağlayabilmektedir. Bunun yanı sıra kişilerin çevresine zarar verme ihtimalleri de ayrıca kısıtlanma tedbirinin uygulanmasını gerektirebilmektedir.

Genellikle yaşla beraber fiziksel sorunların artış göstermesi, başta demans gibi hastalıklar sonucunda bilişsel yetilerin azalması sonucu kişilerin vesayet altına alınması talebi ortaya çıkmaktadır (5). Bu nedenle, pratikte geriatrik popülasyonda hukuki ehliyetin değerlendirilmesi s1k yapılmaktadır. Ancak 65 yaş altındaki kişiler hakkında da hukuki ehliyetin değerlendirilmesi söz konusu olmaktadır.

Çalışmamızda hukuki ehliyetin değerlendirildiği 1865 yaş aralığındaki kişilerde en çok rastlanılan hastal1ğın mental retardasyon $(\% 31, n=34)$ olduğu tespit edildi. Daha önce yapılan çalışmalarda adli psikiyatrik gözlem amaçlı yatırılan şahıslarda en çok antisosyal kişilik bozukluğu tanısı konulduğu (6), geriatrik yaş grubunu içe-

Tablo 1. Tanı Sonuç İlişkisi.

\begin{tabular}{|c|c|c|c|c|c|c|c|c|c|c|c|}
\hline \multicolumn{12}{|c|}{ Tan1- Sonuç İlişkisi } \\
\hline & \multicolumn{2}{|c|}{$\begin{array}{c}\text { Vesayet altına } \\
\text { alınma (TMK } \\
405)\end{array}$} & \multicolumn{2}{|c|}{$\begin{array}{c}\text { Vasi ya da } \\
\text { yasal danışman } \\
\text { atanmasına gerek } \\
\text { olmayanlar }\end{array}$} & \multicolumn{2}{|c|}{$\begin{array}{l}\text { Kendi isteği } \\
\text { doğrultusunda } \\
\text { kisitlanma } \\
\text { (TMK 408) }\end{array}$} & \multicolumn{2}{|c|}{$\begin{array}{c}\text { Yasal } \\
\text { Danışman }\end{array}$} & \multicolumn{2}{|c|}{$\begin{array}{l}\text { Kötü yaşam tarzı/ } \\
\text { kötü yönetim } \\
\text { halinde k1sitlanma } \\
\text { (TMK 406) }\end{array}$} & \multirow{2}{*}{$\begin{array}{c}\text { Toplam } \\
20\end{array}$} \\
\hline $\begin{array}{c}\text { Şizofreni } \\
\text { Spektrumu ve } \\
\text { Diğer Psikotik } \\
\text { Bozukluklar }\end{array}$ & $\% 75$ & $\mathrm{n}=15$ & $\% 15$ & $\mathrm{n}=3$ & $\% 0$ & $\mathrm{n}=0$ & $\% 10$ & $\mathrm{n}=2$ & $\% 0$ & $\mathrm{n}=0$ & \\
\hline $\begin{array}{l}\text { Alkol-Madde } \\
\text { Bağımlılığ }\end{array}$ & $\% 0$ & $\mathrm{n}=0$ & $\% 0$ & $\mathrm{n}=0$ & $\% 0$ & $\mathrm{n}=0$ & $\% 0$ & $\mathrm{n}=0$ & $\% 100$ & $\mathrm{n}=10$ & 10 \\
\hline $\begin{array}{c}\text { Bipolar } \\
\text { Bozukluk } \\
\text {-Nekahat }\end{array}$ & $\% 14,3$ & $\mathrm{n}=1$ & $\% 85,7$ & $\mathrm{n}=6$ & $\% 0$ & $\mathrm{n}=0$ & $\% 0$ & $\mathrm{n}=0$ & $\% 0$ & $\mathrm{n}=0$ & 7 \\
\hline $\begin{array}{c}\text { Bipolar } \\
\text { Bozukluk - Aktif }\end{array}$ & $\% 100$ & $\mathrm{n}=3$ & $\% 0$ & $\mathrm{n}=0$ & $\% 0$ & $\mathrm{n}=0$ & $\% 0$ & $\mathrm{n}=0$ & $\% 0$ & $\mathrm{n}=0$ & 3 \\
\hline $\begin{array}{c}\text { Mental } \\
\text { Retardasyonlar }\end{array}$ & $\% 85,3$ & $\mathrm{n}=2$ & $\% 8,8$ & $\mathrm{n}=3$ & $\% 0$ & $\mathrm{n}=0$ & $\% 5,9$ & $\mathrm{n}=2$ & $\% 0$ & $\mathrm{n}=0$ & 34 \\
\hline $\begin{array}{c}\text { Fiziki } \\
\text { Hastalıklar }\end{array}$ & $\% 66,7$ & $\mathrm{n}=6$ & $\% 11,1$ & $\mathrm{n}=1$ & $\% 22,2$ & $\mathrm{n}=2$ & $\% 0$ & $\mathrm{n}=0$ & $\% 0$ & $\mathrm{n}=0$ & 9 \\
\hline $\begin{array}{c}\text { Diğer } \\
\text { Hastalıklar }\end{array}$ & $\% 28,6$ & $\mathrm{n}=2$ & $\% 42,9$ & $\mathrm{n}=3$ & $\% 14,3$ & $\mathrm{n}=1$ & $\% 0$ & $\mathrm{n}=0$ & $\% 14,3$ & $\mathrm{n}=1$ & 7 \\
\hline Toplam & $\% 62,2$ & $n=56$ & $\% 17,8$ & $n=16$ & $\% 3,3$ & $n=3$ & $\% 4,4$ & $\mathrm{n}=4$ & $\% 12,1$ & $\mathrm{n}=11$ & 90 \\
\hline
\end{tabular}


ren bir çalışmada ise Alzheimer hastalığg ile serebrovasküler hastalıklarla yüksek oranda karşılaşıldığı (4) bildirilmiştir.

Çalışmamızda 20 (\%19) hastada "Şizofreni Spektrumu ve Diğer Psikotik Bozukluklar" tanısı konulmuş ve bu hastalarla ilgili büyük oranda $(\% 75)$ vesayet altına alınma kararı alınmıştır. Psikotik bozukluk gerçeği değerlendirme yetisini etkilediyse bu kişilerin hukuki ehliyetlerini kullanamayacağı açıktır. Buna ek olarak psikotik bozukluklarda ve özellikle şizofrenide şiddet eğilimlerinin yüksek olduğunu gösteren çalışmalar bulunmaktadır (7). Hem gerçeği değerlendirme yetisini etkilemesi hem de şiddet eğilimi ortaya çıkarması sebebi ile bu grup hastalarda psikotik bozukluğun türü, aktif olup olmadığ hususunda değerlendirilmesi özenle yapılmalıdır. Aktif hastalık belirtileri ile başvuran psikotik bozukluk tanısı almış şahısların adli bir süreç içerisinde gelmiş olsa dahi tedavi ve takip amaçlı hospitalize edilmesinde yarar olduğu düşünülmelidir. Böylece hem şahısların hastalıklarının seyri ile ilgili de daha objektif karar verilebilecek, hem de tedavi alması sağlanarak koruyucu hekimlik görevi gerçekleştirilebilecektir.

Alkol-madde bağımlılığı hastalarında idiosinkratik alkol zehirlenmesi (idiosyncratic alcohol intoxication), alkole bağlı geçici hafıza kaybı (alcoholic blackout), dipsomani (epsilon alkolizm, dipsomania) görülebildiği belirtilmektedir (8). Bunun yanında bağımlı bireylerin adli olaylara karışma, suç işleme, ya da kendisini ve çevresini zora düşürme tehlikesinin olduğu bilinmektedir (9). Çalışmamızda alkol-madde kullanım bozukluğu tespit edilen 10 hastanın tamamı hakkında TMK 406. madde gereğince k1sıtlanabileceği kanaatini belirten rapor düzenlenmiştir. Diğer hasta gruplarından farklı olarak alkol/madde bağımlılarında raporun bu şekilde düzenlenmesinin sebebi yasadaki durumu (kötü yönetim, zora düşürme) hekimin tespit etmesinin istenmemesidir. $\mathrm{Bu}$, daha çok adli tahkikat ile ulaşılabilecek bir sonuçtur (10). Ancak bağımlılığın tespiti için psikiyatrik değerlendirme pratik uygulamalarda sıkça istenmektedir. Asıl amaç gerek hukuk gerek tıp bilimi açısından bağımlı bireylerin tedavi ve rehabilitasyonu ile hem kendilerinin hem de toplumun refahını arttırmaktır (11).

Çalışmamızda az sayıda olmakla birlikte sadece fiziki hastalıkları bulunan şahısların da büyük oranda kısıtlanması lehine karar verildiği görülmektedir. Bu nedenle ister psikiyatri uzmanınca ister adli tıp uzmanınca yapılıyor olsun adli psikiyatrik değerlendirmede özgeçmiş sorgulamasının ve fizik muayenenin önemi büyüktür. Genellikle hekimlerce gözden kaçırılan bir durum olarak, TMK 408. maddesi bu konuda oldukça yararlıdır. İlgili maddeye göre kişilerin kendi istekleri doğrultusunda kısıtlanabile- ceği belirtilmektedir. Anlaşılacağı üzere şahsın hakimlikçe dinlenmesinin yararlı görüldüğü, bilişsel yetileri yerinde şahıslar bu madde gereğince kısıtlanabilmektedir. $\mathrm{O}$ nedenle kişilerin akıl sağlığını etkilemese dahi tüm tıbbi durumlar dikkatle araștırılmalıdır.

Adli psikiyatrik değerlendirme ile ilgili bir çalışmada yaşı daha küçük olan yaşlıların, eğitim seviyesi daha yüksek olanların ve il merkezinde yaşayan yaşlıların yapacakları işlemlerin hukuki anlam ve sonuçlarını daha iyi anladıkları sonucuna ulaşıldığı belirtilmiştir (12). Çalışmamızda 18-65 yaş aralığındaki bireylerden neredeyse üçte birine -34 $(\% 31,5)$ olgu- vesayet altına alınmasının gerekli olmadığı yönünde belirtilen kanaatin de seçilen örneklemle ilgili olduğu düşünülmüştür. Çünkü başka çalışmalarda değerlendirilen geriatrik grupları içeren çalışmalarda bu oranın çok daha düşük olduğu görülmüştür (4). Akla uygun davranma biçimi olarak da düşünülebilecek ayırt etme gücünün değerlendirilmesi kişiye göre değişebilmekte, şartlara göre farklılık arz edebilmektedir (9).

Bu farklılıkları doğru yorumlamak ciddi bir bilgi birikimi ve uzmanlık gerektirmektedir. Sağlık Bakanlığı'nın 10/03/2014 tarihli "Hukuki işlem ehliyetine ilişkin rapor düzenleme yetkisi" konulu genelgede ilgili kanun maddelerine atıfta bulunularak; aile hekimleri dahil tüm hekimlerin hukuki işlem yapma ehliyeti raporu düzenlemeye yetkili olduğu belirtilmektedir. Uygulamada sıklıkla Adli Tip Kurumu 4. İhtisas Kurulu'ndan, Adli Tıp Kurumu Şube Müdürlükleri'nden veya üniversite adli tıp kürsülerinden rapor istenmektedir. Şüphesiz ki böyle özelleşmiş bir alanda bilgili ve tecrübe kazanmış bir hekim grubunun (yan dal eğitimi ile uzmanlaşmış) bir kurul halinde değerlendirmeyi yapması önemlidir. Bu nedenle adli psikiyatri yan dal uzmanlık eğitimi programları ile bu alandaki uzman istihdamının planlanmasında yarar olabileceği belirtilmektedir $(13,14)$. Bizler de hem psikiyatri uzmanlarının hem de adli tıp uzmanlarının ortak bakış açısına ihtiyaç duyulan bu alanda bir yan dal uzmanlık programının oluşturulmasının gerekli olduğu düşüncesindeyiz. Bunun yanında adli psikiyatrik değerlendirmeyi yapan her hekimin ya da kurulun değerlendirme sürecinde ortak bir yol izlemeli, kısıtlamasının gerekli olup olmadığı sorulan şahıslarla ilgili varsa adli dosyaları, tıbbi özgeçmişleri incelenmeli, birinci derece yakınları ile görüşmeler yapılmalı ve şahısları gerekli gördüğünde hospitalize etmelidir. Bunun yanında muayene sonrası tanı süreci önemli olduğu kadar birey için kapasite yitimini özgül biçimde tanımlayan bir işlevsel değerlendirme de gereklidir (15).

Raporlandırma sürecinde; şahıs ile ilgili elde edilen tüm bilgi, belge ve muayene bulgularından bahsedilmeli, varsa hastalığın tanımı uluslararası tanı kodları ya da reh- 
berler dikkate alınarak yapılmalı, sonuç bölümünde ilgili kanun maddeleri 1şı̆̆ında kurulun kanaati belirtilmelidir. Böylece ülke çapında standardize raporların ortaya çıkması, adli psikiyatrik değerlendirmenin bir objektivite kazanması sağlanabilecektir.

\section{Kaynaklar}

1. Soysal H. Adli Psikiyatri. İstanbul: Özgür Yayınları; 2012.

2. Kırbaş D. Adli Nöropsikiyatri: Nobel Tıp; 2016.

3. Koç N. Türk Medeni Kanunundaki Düzenlemeler Işığında Vesayet Hukukuna Genel Bir Bakış, DEÜHFD, 2005;7: 99 120

4. Cavlak M, Odabasi Balseven A, Akcan R, Yildirim MŞ, Lale A, Heybet ER, et al. Assessment of legal capacity in the geriatric population: a retrospective study. Turkish Journal of Geriatrics/Türk Geriatri Dergisi. 2014;17(4):350-355

5. Moye J, Marson DC. Assessment of decision-making capacity in older adults: an emerging area of practice and research. The Journals of Gerontology Series B: Psychological Sciences and Social Sciences. 2007;62(1):3-11. doi: 10.1093/geronb/62.1.P3

6. Bolu A, Toygar M, Pan E, Erdem M, Ünlü G. Bir eğitim hastanesi psikiyatri kliğinde adli olguların değerlendirilmesi; beş yıllık inceleme. Gülhane Tıp Dergisi. 2014; 56:1-4 doi: $10.5455 /$ gulhane. 36271

7. Belli H, Ural C, Vardar MK, Tezcan B. Şizofrenide şiddet ve cinayet eylemi: risklerin değerlendirilmesi, önleyici tedbirler ve tedavide klozapinin yeri. Düşünen Adam Psikiyatri ve Nörolojik Bilimler Dergisi. 2011; 24:222-7. DOI: 10.5350/DAJPN2011240308
8. Demirel OF, Balcioglu I. Alkol ve Madde Bağımlılığında Ceza Sorumluluğu ve Fiil Ehliyeti. New Yeni Symposium 2015; 53:27-33 DOI: 10.5455/NYS.20150309011520

9. Copoglu US, Bülbül F, Kokaçya MH, Alıcı D, Taştan MF, Ünal A, et al. Adli psikiyatri polikliniğinde değerlendirilen olguların psikiyatrik tanıları, madde kullanım durumları, sosyo-demografik ve klinik özellikleri. New. New/ Yeni Symposium Journal; 2014:52(1);1-6 DOI: 10.5455/ NYS.20140827121119

10. Özden SY. Adli Psikiyatri. Ankara: Nobel; 2015.

11. Tosun M, Çetin A, Konuk N. Alkol ve madde bağımlılığının adli psikiyatrik yönleri. Turkiye Klinikleri Journal of Psychiatry Special Topics. 2011;4(1):81-90.

12. Karbeyaz K, Akkaya H, Gündüz T, Urazel B, Kökçüoğlu MA. Yaşlılık Nedeniyle Düzenlenen Fiili (Hukuki) Ehliyet Raporları; Eskişehir Deneyimi. Adli Tıp Dergisi. 2013;27(1):10-6. doi:10.5505/adlitip.2013.93695

13. Savrun BM. Türkiye'de Adli Psikiyatri Uygulamaları. Turkiye Klinikleri Journal of Psychiatry Special Topics. 2011;4(1):60-6.

14. Arcese G, Drunat O, Arbault S, Gonthier R. Evaluation of the quality of medical certificates in the context of the opening of a measure of legal protection for adults over 60 years of age. Gériatrie et Psychologie Neuropsychiatrie du Vieillissement 2017:15(2);145-152. DOI: 10.1684/ pnv.2017.0664

15. Kalenderoğlu, A, Yumru M, Selek S, Savaş HA. Gaziantep Üniversitesi tıp fakültesi adli psikiyatri birimine gönderilen olguların incelenmesi. Nöropsikiyatri Arşivi/Archives of Neuropsychiatry 2007; 44: 86-90 